\title{
20: 35318706-35312903
}

National Cancer Institute

\section{Source}

National Cancer Institute. 20:35318706-35312903. NCI Thesaurus. Code C42377.

Physical location of GHRH_Gene 